\title{
Introducing Sex Education To Children Through Pictures And Singing
}

\author{
Ainul Hasanah \\ Received: 27032021 / Accepted: 10062021 / Published online: 30062021 \\ (C) 2021 Association of Indonesian Islamic Early Childhood Education Study Program
}

\begin{abstract}
Abstrak Pendidikan seks perlu diperkenalkan sejak dini sebagai upaya memberikan pemahaman bagi anak tentang peran seksualitasnya dan sebagai upaya pencegahan kekerasan seksual pada anak. Pendidikan anak usia dini harus dilaksanakan sesuai dengan kebutuhan dan tahapan perkembangan anak, maka proses pendidikan anak usia dini harus dikemas dalam bentuk yang menarik dan menyenangkan bagi anak. Penelitian ini bertujuan untuk mengetahui bagaimana penerapan pengenalan pendidikan seks pada anak dengan menggunakan media yang menarik dan menyenangkan bagi anak yaitu media gambar dan metode bernyanyi. Subjek dalam penelitian ini adalah anak usia 5-6 tahun sebanyak 30 siswa dan guru sebanyak 9 orang di TK Muslimat NU VI Pademawu Pamekasan. Adapun metode pengumpulan data dalam penelitian ini berupa observasi, wawancara, dan dokumentasi. Analisis data yang digunakan adalah model Miles dan Huberman. Hasil penelitian menunjukkan bahwa Pengenalan pendidikan seks pada anak dilaksanakan dalam beberapa bentuk yaitu pendidikan kesehatan diri dan pengenalan pendidikan seks melalui media gambar dan metode bernyanyi.
\end{abstract}

Kata Kunci: pendidikan seks, media gambar, metode bernyanyi

\begin{abstract}
Sex education needs to be introduced from an early age as an effort to provide understanding for children about the role of their sexuality and as an effort to prevent sexual violence against children. Early childhood education must be implemented in accordance with the needs and stages of child development, then the process of early childhood education must be packaged in an attractive and fun form for children. This study aims to determine how the application of the introduction of sex education to children using interesting and fun media, namely the media of images and the singing method. The subjects in this study were 30 students aged 5-6 years and 9 teachers at TK Muslimat VI NU Pademawu Pamekasan. The data collection methods in this research are observation, interview, and documentation. The data analysis used was the Miles and Huberman model. The results showed that the introduction of sex education in children by personal health and sex education through the media of pictures and the singing method.
\end{abstract}

Keywords: sex education, media of pictures, singing method

\section{Pendahuluan}

Masa usia dini adalah masa yang paling potensial dalam berbagai aspek perkembangan tidak terkecuali dalam memberikan pendidikan dan pengarahan. Pendidikan anak usia dini dimaksudkan untuk memberikan stimulasi yang optimal bagi tumbuh kembang anak dari lahir sampai usia enam tahun baik pada aspek fisik maupun non fisik dengan memberikan rangsangan pada perkembangan jasmai dan rohani (agama dan moral, motorik, kognitif, sosial dan emosional (Mansur, 2014). Demikian halnya dengan pentingnya pendidikan seksualitas bagi anak usia dini yang masih dianggap sebagai sesuatu yang tabu oleh sebagian kalangan 
masyarakat yang beranggapan bahwa anak usia dini masih terlalu kecil untuk memahami tentang seksualitas sehingga tidak perlu dikenalkan pada anak. Padahal melihat kenyataan sekarang banyaknya kasus kekerasan dan pelecehan seksual dimana korbannya adalah anakanak. Kekerasan dan pelecehan seksual akan meninggalkan pengalaman traumatis bagi anak yang akan mengganggu proses tumbuh kembang anak dan akan mengakibatkan muculnya gangguan seksualitas pada anak apabila tidak segera ditangani secara tepat(Haryono, Anggraini, Muntomimah, \& Wahyudi, 2018, p. 25). Beberapa kasus anak yang menjadi korban child sexual abuse justru pelakunya adalah orang-orang yang dekat dan punya hubungan keluarga dengan anak. Mereka tidak memahami adanya potensi bahaya di sekitar mereka karena anak-anak memiliki kecenderungan untuk percaya dan dekat dengan orang-orang disekitarnya. Briggs dan Hawkins sebagaimana dikutip oleh Solihin menyebutkan bahwa ada beberapa hal yang memungkinkan anak mudah menjadi sasasaran child sexual abuse yaitu anak-anak yang mudah percaya pada semua orang di sekitarnya karena kepolosannya, usia yang masih belia membuat mereka tidak mampu mengenali motif-motif yang dimiliki orang dewasa, anak-anak yang diajari untuk selalu menuruti orang dewasa, dan anak-anak yang sama sekali jauh dari pengenalan dan informasi tentang seksualitas mereka (Solihin, 2015, p. 58). Maka pengenalan pendidikan seksualitas sejak usia dini menjadi hal penting serta mendesak untuk dilakukan. Lebih lanjut adanya pengenalan pendidikan seks sejak dini dimaksudkan agar anak dapat tumbuh dan berkembang dengan pribadi yang sehat, harga diri yang tinggi, memmiliki rasa percaya diri, dan penerimaan diri yang positif (Zubaedah, 2016, p. 62)

Pemberian pendidikan seksualitas untuk anak usia dini tentunya tidak sama dengan pemberian pendidikan seksualitas kepada remaja atau orang dewasa. Pendidikan seksualitas untuk anak harus disesuaikan dengan tahapan perkembangan dan tingkat pemahaman anak. Pendidikan seks sejak dini diarahkan untuk memberikan pemahaman kepada anak tentang pengenalan perbedaan gender sehingga anak akan betul-betul paham perbedaan laki-laki dan perempuan serta peran-perannya, pengenalan fungsi alat seksual, bimbingan mengenai pentingnya memelihara dan menjaga organ intim, pemahaman tentang pergaulan yang sehat, serta seputar beberapa resiko timbulnya permasalahan seksualitas (Haryono, 2018, p.26). Pengenalan pendidikan seks pada anak dapat dimulai dengan mengenalkan anggota tubuh dan fungsinya, dan diajarkan bagaimana membersihkan tubuh dan alat kelaminnya sendiri yang hal ini akan mengajarakan anak untuk bisa mandiri dan tidak tergantung pada orang lain (Mukti, 2016, p. 94).

Dunia anak adalah dunia bermain. Masa anak-anak adalah masa untuk bersenangsenang dengan bermain. Bermain merupakan salah satu pendekatan yang dapat digunakan dalam melaksanakan kegiatan pendidikan bagi anak usia dini dengan berbagai macam metode dan berbagai jenis media yang menarik dan menyenangkan bagi anak. Melalui kegiatan bermain memberikan kesempatan bagi anak untuk bereksplorasi, berekspresi, berkreasi, dan dapat membantu mengenal diri sendiri dengan cara yang menyenangkan (Indrijati, 2017). Dalam konsep belajar sambal bermain pada anak usia dini diperlukan penggunaan metode dan alat bermain atau media yang menarik dan mudah dipahami oleh anak.

Media gambar merupakan media pembelajaran yang sangat menarik bagi anak karena dalam media gambar anak akan dapat melihat secara langsung berbagai macam bentuk dan warna-warna yang menarik bagi anak. Media gambar dapat meningkatkan konsentrasi anak karena anak akan lebih fokus memperhatikan apa yang ada di gambar dan anak akan lebih mudah memahami informasi yang disajikan melalui gambar (Khotimah, Sunaryati, \& Suhartini, 2021, p. 679).

Selain penggunaan media yang menarik, seorang guru juga harus pandai memilih metode pembelajaran yang tepat dan menyenangkan bagi anak. Metode bernyanyi adalah salah satu metode yang sangat disukai anak-anak. Dengan bernyanyi akan membuat suasana pembelajaran menjadi riang dan bergairah(Lestari \& Erik, 2017, p. 2). Tujuan yang dapat dicapai dengan penggunaan metode bernyanyi pada anak usia dini adalah memupuk irama dan estetis, memperkaya perbendaharaan kosakata, mengembangkan bahasa, melatih daya ingat, dan yang terpenting dengan bernyanyi akan memberikan kepuasan, kegembiraan, dan kebahagiaan 
pada anak (Dewi, Putra, \& Suniasih, 2017, p. 142). Penerapan metode dan penggunaan media yang menarik, mudah dipahami, dan menyenangkan bagi anak akan memberikan kemudahan pada guru dalam menyampaikan materi pembelajaran yang sesuai dengan kebutuhan dan perkembangan anak. Oleh karena itu maka tujuan dari penelitian ini adalah untuk mengetahui bagaimana implementasi pengenalan pendidikan seks pada anak usia dini melalui media gambar dan metode bernyanyi di TK Muslimat NU VI Pademawu Pamekasan.

\section{Metode}

Penelitian ini menggunakan jenis penelitian dengan pendekatan kualitatif deskriptif. Penelitian kualitatif deskriptif adalah penelitian ini dimaksudkan untuk mengeksplorasi atau mengklarifikasi suatu gejala, fenomena atau kenyataan sosial yang ada (Samsu, 2017). Lokasi penelitian ini adalah TK Muslimat NU VI yang terletak di Dusun Mondung RT/RW 05/05 Desa Dasok Kecamatan Pademawu Kabupaten Pamekasan Madura. Subyek penelitian ini adalah 4 orang guru dan 15 siswa kelas B usia 5 - 6 tahun. Data penelitian diperoleh melalui observasi, wawancara dan dokumentasi. Analisis data dalam penelitian ini adalah model Miles dan Huberman.Untuk memperoleh keabsahan data peneliti menggunakan pemeriksaan keabsahan data melalui triangulasi. Triangulasi merupakan teknik untuk menguji keterpercayaan data (memeriksa keabsahan data) dengan memanfaatkan hal-hal lain diluar data untuk melakukan pengecekan atau sebagai pembanding terhadap data tersebut (Samsu, 2017).

\section{Hasil Penelitian}

Pengenalan pendidikan seks pada anak di TK Muslimas NU Pademawu Pamekasan mengacu pada KD 3.4 dan 4.4. Tema dan sub tema yang biasa digunakan untuk pengenalan seks pada anak adalah tema Diri Sendiri dengan sub tema Tubuhku.

Table 1. Pengembangan Materi Pembelajaran pengenalan pendidikan seks di TK Muslimat NU VI Pademawu Pamekasan merujuk pada Kurikulum 13 PAUD

\begin{tabular}{|c|c|c|c|}
\hline $\begin{array}{c}\text { PROG. } \\
\text { PENGEMBANGAN }\end{array}$ & KD & INDIKATOR & $\begin{array}{c}\text { MATERI } \\
\text { PEMBELAJARAN }\end{array}$ \\
\hline FISIK MOTORIK & $\begin{array}{l}\text { 2.1. Memiliki } \\
\text { perilaku } \\
\text { yang } \\
\text { mencermi } \\
\text { nkan } \\
\text { hidup } \\
\text { sehat }\end{array}$ & $\begin{array}{l}\text { 1. Terbiasa makan-makanan } \\
\text { bergizi seimbang } \\
\text { 2. Terbiasa memelihara } \\
\text { kebersihan diri dan } \\
\text { lingkungan dengan terbiasa } \\
\text { melakukan aktivitas bersih- } \\
\text { bersih mengembalikan } \\
\text { barang pada tempatnya, } \\
\text { menyiram tanaman di sekitar } \\
\text { lingkungan sekolah } \\
\text { 3. Terbiasa makan-makanan } \\
\text { bergizi seimbang } \\
\text { 4. Terbiasa memelihara } \\
\text { kebersihan diri dan } \\
\text { lingkungan } \\
\text { 5. Terbiasa makan- } \\
\text { makanan bergizi seimbang }\end{array}$ & $\begin{array}{l}\text { 1. Kebiasaan merawat diri } \\
\text { misalnya; mencuci tangan, } \\
\text { menggosok gigi, mandi, } \\
\text { berpakaian bersih, } \\
\text { 2. Kebiasaan anak makan } \\
\text { makanan bergizi seimbang, } \\
\text { 3. Menjaga kebersihan } \\
\text { lingkungan misalnya; } \\
\text { kebersihan tempat belajar } \\
\text { dan lingkungan, menjaga } \\
\text { kebersihan alat main dan } \\
\text { milik pribadi }\end{array}$ \\
\hline & $\begin{array}{l}\text { 3.4.Mengetahu } \\
\text { i cara } \\
\text { hidup } \\
\text { sehat } \\
\text { 4.4.Mampu } \\
\text { menolong } \\
\text { diri sendiri } \\
\text { untuk } \\
\text { hidup }\end{array}$ & 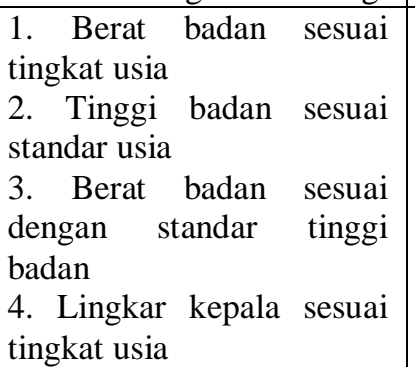 & $\begin{array}{l}\text { 1. Cara merawat kebersihan } \\
\text { diri (misal: mencuci tangan, } \\
\text { berlatih toilet, merawat gigi, } \\
\text { mulut, telinga, hidung, } \\
\text { olahraga, mandi } 2 x \text { sehari; } \\
\text { memakai baju bersih) } \\
\text { memilih makanan dan } \\
\text { minuman yang sehat, } \\
\text { makanan yang diperlukan }\end{array}$ \\
\hline
\end{tabular}




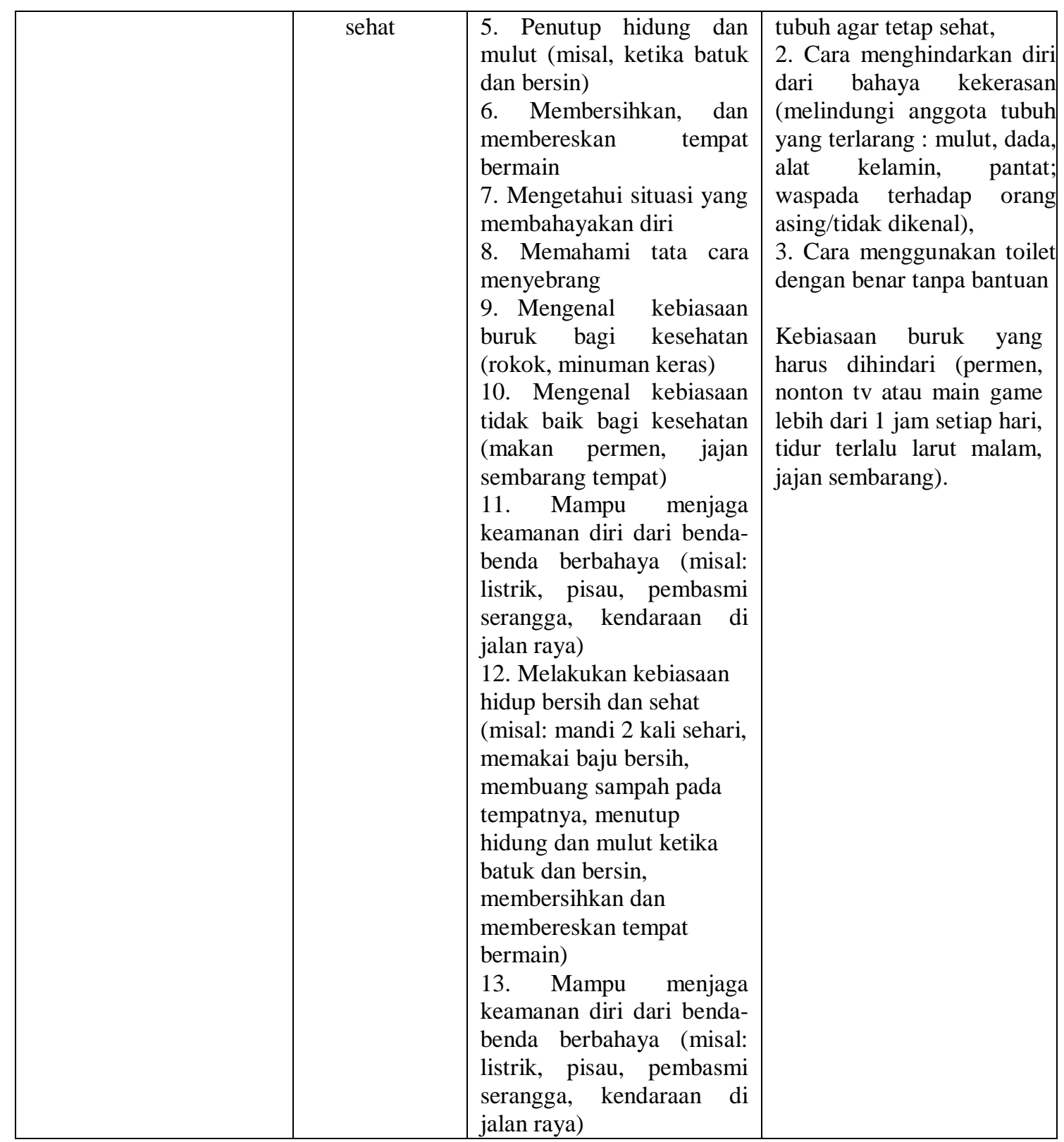

\section{Pengenalan Pendidikan Kesehatan Melalui Pembiasaan Dan Metode Bernyanyi}

Lirik lagu tentang pentingnya mencuci tangan : "ayo cuci tangan sebelum makan....cuci tangan bersih digosok kanan kiri....mari menjaga kebersihan tangan....tangan yang bersih kuman lari semua...hore....".

Hasil wawancara dengan salah seorang guru bernama Zahrotun Naimah yang sekaligus menjabat sebagai kepala TK mengatakan bahwa "anak-anak dibiasakan mencuci tangan sebelum dan sesudah beraktivitas terutama juga pada saat sebelum makan agar anak terbiasa menjaga kesehatan dan kebersihan diri. Selain pembiasaan mencuci tangan di TK Muslimat NU VI Pademawu Pamekasan ini juga menggunakan metode bernyanyi tentang teknik atau cara mencuci tangan yang baik dan benar serta manfaatnya untuk kesehatan. Dalam metode bernyanyi guru mempraktekkan langsung bagaimana cara mencuci tangan sesuai dengan lirik lagu yang kemudian diikuti oleh anak-anak. Kenapa hal ini perlu diberikan kepada anak agar anak terlebih dahulu mengetahui dan memahami tentang pentingnya menjaga kesehatan diri yang nantinya akan berguna ketika anak dikenalkan pada pendidikan seks sebagai upaya untuk menjaga keselamatan diri” (Zahrotun Naimah, 2021). 


\section{Pengenalan Keselamatan Diri Melalui Pendidikan Seks Menggunakan Media Gambar}
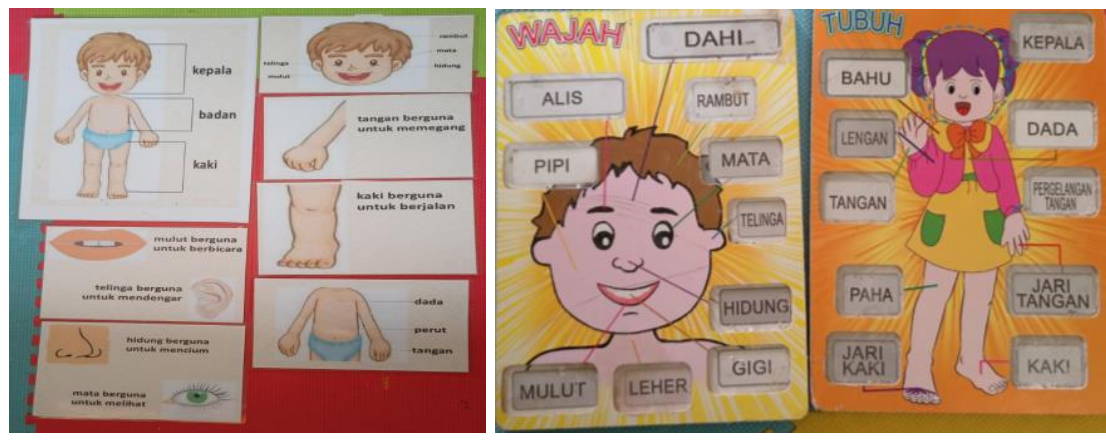

Gambar 1. Nama-nama Anggota Tubuh dan Fungsinya

Hasil wawancara tentang pendidikan seks melalui media gambar dengan salah seorang guru kelas B bernama Juhairiyah yaitu "kami biasanya mengenalkan pendidikan seks pada anak menggunakan gambar anggota tubuh yang diawali dengan pertanyaan apa nama anggota tubuh yang ditunjuk. Kami memberikan kesempatan pada anak untuk menjawab dulu tanpa diberitahu oleh guru, dan jika ada jawaban yang salah maka guru menjelaskan. Melalui media gambar ini pula kami juga menanyakan pada anak bagian mana anggota tubuh anak yang boleh dan tidak boleh disentuh oleh orang lain yang juga disertai penjelasan dari guru jika anak tidak mampu menjawab dengan tepat. Kegiatan ini biasa dilaksanakan pada tema Diri Sendiri subtema tubuhku baik di dalam maupun di luar kelas" (Juhariyah, 2021).

\section{Pengenalan keselamatan diri melalui pendidikan seks menggunakan metode bernyanyi}

Lirik lagu tentang sentuhan boleh dan sentuhan tidak boleh "sentuhan boleh, sentuhan boleh....kepala, tangan, kaki...karena sayang, karena sayang, karena sayang....sentuhan tidak boleh, setuhan tidak boleh...terttutup baju dalam...hanya diriku, hanya diriku, yang boleh menyentuh...."

Hasil wawancara tentang pendidikan seks melalui metode bernyanyi sebagaimana diungkapkan oleh ibu Siti Halilatul Jannah selaku guru kelas B "setelah kami melakukan tanya jawab tentang anggota tubuh dan bagian anggota tubuh yang boleh dan tidak boleh disentuh, maka kami lanjutkan dengan metode bernyanyi yang disertai gerakan (gerak dan lagu)"(Jannah, 2021).

\section{Pembahasan}

Pelaksanaan pendidikan harus disesuaikan dengan tingkat atau tahapan perkembangan individu. Demikian halnya dengan pendidikan anak usia dini yang harus disesuaikan dengan kebutuhan anak. Pada masa usia dini anak membutuhkan berbagai macam stimulasi yang berhubungan dengan semua aspek perkembangan anak baik fisik maupun psikis yang meliputi aspek kognitif, nilai agama dan moral, bahasa, fisik motorik, dan sosial emosional. Maka kegiatan pembelajaran pada jenjang PAUD harus berorientasi pada kebutuhan anak yang mencakup layanan pendidikan, kesehatan, dan gizi yang dilaksanakan secara holistik dan integratif (Indrijati, 2017). Tak terkecuali dengan pendidikan seks bagi anak usia dini yang harus mendapatkan perhatian penting dari berbagai pihak terutama dari orang tua sebagai lingkungan yang pertama dan utama bagi anak, dan guru sebagai sosok ideal bagi anak yang sangat dipercaya dan selalu dipatuhi serta ditiru oleh anak.

Kegiatan pembelajaran di PAUD akan berjalan efektif apabila didukung dengan penggunaan media dan sumber belajar serta metode yang menarik dan mudah dipahami oleh anak. Efektivitas media dan metode pembelajaran juga sangat ditentukan oleh keterampilan guru dalam menggunakannya karena media hanya sebagai sarana penyampaian informasi 
pembelajaran, sedangkan guru adalah kunci pokok dalam proses pembelajaran tersebut. Maka keahlian dan keterampilan guru dalam memilih dan menggunakan media maupun metode pembelajaran dengan penguasaan teknik dan memahami manfaat penggunaan media pembelajaran mutlak diperlukan (Fadlillah, 2016).

Pendidikan seks bagi anak usia dini di TK Muslimat NU dusun Mondung desa Dasok kecamatan Pademawu Pamekasan adalah bagian dari proses pembelajaran yang berorientasi pada kebutuhan dan tahapan perkembangan anak. Hal ini merupakan bentuk implementasi dari salah satu kompetensi dasar yang harus dimiliki oleh anak pada aspek kesehatan dan keselamatan anak. Pengenalan pendidikan seks pada anak di TK Muslimat NU dusun Mondung desa Dasok kecamatan Pademawu Pamekasan dilaksanakan pada tema diri sendiri sub tema tubuhku dengan mengacu pada program pengembangan, kompetensi dasar (KD), indikator, dan materi pembelajaran. Namun adakalanya pengenalan pendidikan kesehatan dan seks pada anak dilakukan secara insidental untuk mengingatkan kembali materi pendidikan seksualitas pada anak.

Berdasarkan hasil pengamatan dan wawancara, peneliti menemukan bahwa pengenalan pendidikan seks pada anak diarahkan pada hal bagaimana menjaga kesehatan dan keselamatan diri yaitu melalui pembiasaan mencuci tangan dan pendidikan seksualitas melalui pengenalan bagian tubuh anak yang boleh dan tidak boleh disentuh menggunakan media gambar dan metode bernyanyi.

\section{Pengenalan cara menjaga kesehatan diri melalui pembiasaaan dan metode bernyanyi di TK Muslimat NU VI Pademawu Pamekasan}

Salah satu bagian terpenting dalam kehidupan seorang anak adalah bagaimana menjaga kesehatan dan kebersihan. Kesehatan merupakan aspek pertumbuhan dan perkembangan yang harus mendapatkan stimulasi yang memadai dari lingkungan sekitar dalam proses tumbuh kembang anak. Di TK Muslimat NU VI Pademawu Pamekasan pendidikan tentang menjaga kesehatan dikenalkan pada anak dalam bentuk pembiasaan sehari-hari dan melalui penggunaan metode bernyanyi. Dalam kegiatan bernyanyi guru bersama-sama anak didik mempraktekkan tentang teknik mencuci tangan yang benar dan manfaatnya. Hal ini dimaksudkan agar anak mudah memahami bagaimana cara mencuci tangan yang baik dan benar. Dengan menggunakan metode bernyanyi anak mudah menghafal lirik lagu dan mudah mengingat pesan yang ingin disampaikan yaitu tentang cara mencuci tangan beserta manfaatnya bagi kesehatan. Hal ini sesuai dengan apa yang dinyatakan dalam hasil sebuah penelitian bahwa pengenalan pendidikan kesehatan melalui metode bernyanyi tentang teknik mencuci tangan mempunyai pengaruh yang signifikan terhadap keterampilan anak dalam mencuci tangan yang baik dan benar. Melalui kegiatan bernyanyi belajar penddidikan akan terasa lebih menyenangkan bagi anak dan membantu anak mudah menyerap pesan dari lagu yang dinyanyikan (Idayanti, vidya, Mustikasari, 2017 p.50).

Selain penggunaan metode bernyanyi TK Muslimat NU Pademawu Pamekasan membiasakan anak untuk mencuci tangan setiap hari di sekolah. Guru membimbing anak untuk terbiasa mencuci tangan sebelum dan sesudah beraktivitas, ketika akan makan dan sesudah makan. Bimbingan ini dilakukan secara berulang-ulang melalui praktek langsung. Hal ini sesuai dengan hasil penelitian bahwa seorang guru atau pendidik harus memberikan pendidikan kesehatan kepada anak didik secara berulang-ulang tentang pentingnya mencuci tangan sebelum dan sesudah makan dengan bimbingan yang terus-menerus sehingga akan menjadi kebiasaan bagi anak. Pembiasaan yang dilakukan pada anak akan membantu anak mengingat dan membiasakan diri dalam berperilaku. Pendidikan kesehatan pada anak yang dilakukan secara konsisten akan menjadikan anak mempunyai kebiasaan perilaku hidup bersih dan sehat sehingga dengan meningkatknya kualitas kesehatan maka angka kesakitan akan berkurang dan anak akan lebih konsentrasi dalam belajar (Idayanti, Vidya, \& Mutikasari, 2017, p. 49). Hal ini juga diperkuat oleh Syarbini sebagaimana yang dikutip oleh Ihsani, Kurniah, dan Suprapti (2018) bahwa pembiasaan yang dilakukan sejak dini akan menjadikan kebiasaan tersebut menjadi semacam adat kebiasaan bagi anak sehingga menjadi bagian yang tidak terpisahkan dalam kepribadian anak. Dalam penelitian lainnya menemukan bahwa anak yang diberi 
penjelasan dan pembiasaan praktek langsung tentang cara mencuci tangan sesuai standar protokol WHO, maka pengetahuan anak tentang teknik mencuci tangan yang baik dan benar meningkat secara signifikan (Suprapto et al., 2020, p. 143).

Pendidikan kesehatan diri akan membantu anak memiliki pengetahuan dasar tentang pentingnya menjaga dan merawat tubuh yang akan sangat berguna ketika mereka beranjak dewasa. Dalam hal ini pula jika anak dibiasakan mengenal bagian-bagian tubuh mereka yang disertai dengan pengetahuan bagaimana cara menjaga dan merawat tubuh, serta diberi pengertian bagaimana cara melindungi anggota tubuhnya, maka anak akan terbiasa dalam menjaga kesehatan dan kebersihan diri, serta anak akan mampu menolong dan melindungi dirinya sendiri dari berbagai macam bahaya yang mengancam dirinya.

Pada dasarnya pendidikan kesehatan yang juga sebagai dasar pengetahuan untuk mengenalkan pendidikan seks bagi anak mempunyai bentuk yang sangat beragam dan variatif tergantung dengan tahapan perkembangan dan kebutuhan anak. Selain mengajarakan anak untuk terbiasa mencuci tangan, hal lain yang tidak boleh diabaikan dalam mengenalkan pendidikan kesehatan dan seksual pada anak adalah mengajari anak membersihkan alat kelaminnya. Mengajari anak membersihkan alat kelamin bisa dimulai dengan mengajari anak untuk tidak buang air kecil atau buang air besar di sembarang tempat. Kemudian penting juga mengajari anak untuk bisa mandiri dalam membersihkan alat kelamin setelah buang air kecil atau buang air besar. Hal ini dimaksudkan untuk menanamkan rasa malu pada anak sedini mungkin sehingga anak terbiasa menjaga dirinya dari pandangan orang lain (Chomaria, 2012).

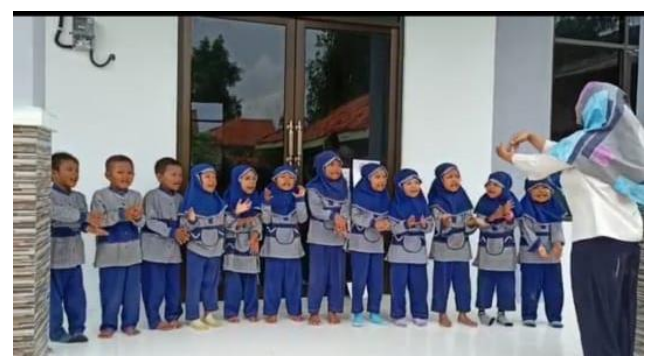

Gambar 2. Mengajari cara mencuci tangan melalui metode bernyanyi

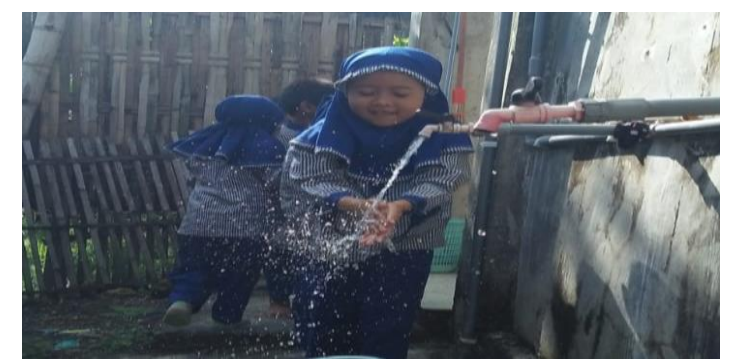

Gambar 3. Praktek pembiasaan mencuci tangan

Menjaga kesehatan diri yang dalam hal ini adalah kegiatan mencuci tangan harus dikenalkan dan dibiasakan sejak usia dini mengingat anak adalah generasi penerus bangsa yang harus ditopang dengan jiwa dan raga yang kuat dan sehat. Pembiasaan mencuci tangan bagi anak selain untuk melatih anak terbiasa menjalankan perilaku hidup bersih dan sehat dalam kehidupan sehari-hari, juga untuk menghindarkan anak dari berbagai penyakit yang mudah menyerang anak seperti sakit perut, diare, dan sebagainya. Dengan fisik yang sehat dan jiwa yang kuat maka proses belajar akan berjalan dengan baik dan lancar.

\section{Pengenalan cara menjaga keselamatan diri melalui pendidikan seks menggunakan media gambar dan metode bernyanyi}

Seksualitas adalah bagian yang tidak dipisahkan dari kehidupan manusia karena merupakan salah satu fitrah dari penciptaan manusia. Pendidikan seksualitas perlu dikenalkan pada anak sejak usia dini dengan tujuan untuk mengenalkan tentang ciri-ciri seksualitas anak 
yang harus diketahui dan dipahami oleh anak sebagai bekal pendidikan seksualitas di masa selanjutnya. Tujuan pendidikan seks pada anak berbeda sesuai dengan tingkat usia dan perkembangannya. Untuk usia balita pendidikan seks dimaksudkan untuk memperkenalkan organ seks yang dimiliki, seperti menjelaskan anggota tubuh lainnya, termasuk menjelaskan fungsi serta cara melindunginya. Untuk usia sekolah mulai 6-10 tahun bertujuan memahami perbedaan jenis kelamin (laki-laki dan perernpuan), menginformasikan asal-usul manusia, membersihkan alat genital dengan benar agar terhindar dari kuman dan penyakit. Sedangkan usia menjelang remaja, pendidikan seks bertujuan untuk menerangkan masa pubertas dan karakteristiknya,serta menerima perubahan dari bentuk tubuh (Ratnasari \& Alias, 2016, pp. 5657). Lebih lanjut Finkelhor sebagaimana dikutip oleh Aggraini, Riswandi, dan Sofia (2017) menyatakan bahwa tujuan pendidikan seks adalah agar anak dapat mengidentifikasi situasisituasi berbahaya dan mencegah terjadinya pelecehan seks, serta mengajarkan pada anak bentuk-bentuk sentuhan yang tidak baik, bagaimana cara menolak atau mengakhiri interaksi dengan pelaku atau orang yang mencurigakan, serta bagaimanacara mereka meminta pertolongan (Anggraini, Riswandi, \& Sofia, 2017, p. 3).

Pengenalan pendidikan seks pada anak di TK Muslimat NU Pademawu Pamekasan salah satunya menggunakan media gambar tubuh. Pertama-tama guru akan mengajukann pertanyaan kepada anak didik tentang nama-nama bagian anggota tubuh yang ada di gambar mulai dari kepala, tangan, kaki, dan sebagainya. Setelah itu guru juga akan menanyakan tentang beberapa fungsi dari bagian-bagian tubuh tersebut. Apabila anak tidak mampu menjawab pertanyaan guru maka guru akan menjelaskan tentang fungsi-fungsi dari bagian-bagian tubuh tersebut. Salah satu contoh guru menunjuk gambar tangan dengan pertanyaan "ayo siapa yang tahu ini apa?" maka anak didik serentak akan menjawab "tangan". Kemudian guru menanyakan "apa fungsi tangan?", disini beragam jawaban yang dilontarkan oleh anak ada yang menjawab untuk menulis, makan, memegang, dan sebagainya. Disinilah guru kemudian menjelaskan tentang beberapa fungsi tangan yaitu salah satunya untuk memegang. Demikian seterusnya bentuk pertanyaan untuk anggota tubuh yang lain seperti kepala, hidung, mulut, kaki, dan lainnya. Setelah bertanya jawab dan menjelaskan tentang fungsi anggota tubuh, kemudian guru menjelaskan tentang bagian-bagian tubuh yang boleh dan tidak boleh disentuh, yang kemudian dilanjutkan dengan tanya jawab kembali tentang hal tersebut. setelah anak didik mampu menjawab semua pertanyaan guru kemudian dilanjutkan dengan bernyanyi bersama-sama tentang bagian-bagian tubuh yang boleh dan tidak boleh disentuh oleh orang lain. Agar anak lebih semangat dan mudah memahami materi pembelajaran, penggunaan metode bernyanyi disertai dengan gerakan-gerakan sesuai dengan lirik lagu yang dibawakan oleh guru dan anak didik.

Pada masa usia awal anak-anak kecenderungan dan minat anak untuk mengetahui bagian-bagian anggota tubuh sangat besar yang ditandai dengan rasa ingin tahu terhadap perbedaan anatomis laki-laki dan perempuan. Setelah itu anak akan tertarik untuk memberikan komentar tentang berbagi bagian tubuh dengan mengajukan banyak pertanyaan (Hurlock, 1991). Pendidikan seks pada anak dapat dikenalkan melalui beberapa tahapan, yaitu pertama, mengenalkan anatomi bagian tubuhnya yang disertai dengan penjelasan tentang fungsi pada setiap bagian tersebut dengan menggunakan bahasa sederhana, misalnya mata fungsinya untuk melihat. Kedua, membangun kebiasaan positif pada anak misalnya tidak pipis sembarangan, dan menutup bagian tubuh yang tidak pantas dilihat. Ketiga, menanamkan pentingnya menjaga organ tubuh seperti bagian tubuh yang boleh disentuh dan tidak boleh disentuh orang lain. Dalam hal ini materi yang dapat disampaikan berupa materi my bodies belong to me (tubuhku adalah milikku). Anak dapat diberi pengetahuan tentang underware rules yaitu bahwa mereka memiliki daerah-daerah tertentu pada bagian tubuh seperti dada, paha, bokong, bagian celana dalam yang hanya boleh disentuh oleh orang-orang tertentu (Azzahra, 2020, p. 83). Keempat, membiasakan anak berpakaian sesuai dengan identitas jenis kelaminnya (Zubaedah, 2016, p. 62). Kelima, memberi nama yang sesuai dengan jenis kelamin anak. Nama mewakili jenis kelamin pemiliknya, pemberian nama yang tidak sesuai gender akan menyebabkan anak berperilaku sesuai dengan namanya. Pemberian nama perempuan pada anak laki-laki akan 
menyebabkan anak menginternalisasi nilai-nilai perempuan ke dalam sikap dan perilakunya, demikian sebaliknya. Keenam, memberi perlakuan yang sesuai dengan jenis kelamin anak, misalnya anak perempuan diberi mainan boneka, anak laki-laki dibiasakan bermain bola. Hal ini dimaksudkan agar anak mengetahui dan memahami perannya sesuai dengan jenis kelaminnya. Jika anak tidak dibiasakan berperan sesuai jenis kelaminnya dikhawatirkan sikap dan perilaku anak akan menyalahi kodratnya sebagai laki-laki dan perempuan (Chomaria, 2012). Anak lakilaki maupun perempuan yang tidak berperilaku sesuai peran jenis kelaminnya akan mengalami bahaya dalam penggolongan peran seks dimana anak akan memandang perilaku secara berbeda dengan pandangan teman-temannya, misalnya jika ada anak laki-laki yang bermain dengan anak perempuan akan dianggap sebagai "banci" (Hurlock, 1991). Ketujuh, mengajari anak toilet training sebagai bekal untuk melatih anak mandiri dan menanamkan rasa malu sedini mungkin sehingga anak akan terbiasa menutup aurat dari pandangan orang lain (Chomaria, 2012).

Oleh karena itu pemilihan tema dan sub tema di lembaga pendidikan anak usia dini dapat menjadi bahan pertimbangan pemilihan materi pedidikan seks yang akan dikenalkan pada anak. Materi pendidikan seks pada anak bisa berupa Aku dan Tubuhku, Aku dan Pakaianku, Keluarga dan Orang di Sekitar, Merawat Tubuh, dan Menjaga Tubuh. Melalui materi-materi tersebut anak mampu mengetahui dan memahami cara menghindarkan diri dari sexual abuse (kognitif), anak mampu menyadari akan bahaya sexual abuse (afektif), dan anak mampu menolong diri sendiri jika ada bahaya yang mengancam dirinya (psikomotorik) (Jatmikowati, Angin, \& Ernawati, 2015, p. 447). Hasil penelitian tentang implementasi materi pendidikan seks pada anak di TK IT AL-Muhlas Yusro berupa penanaman pentingya rasa malu, penerapan sisi maskulinitas pada anak laki-laki dan feminitas pada anak perempuan, serta latihan toilet training (Fajrin, Junanto, \& Kurniasari, 2020, p. 84).

Pemilihan materi pendidikan seks yang tepat akan membantu anak mudah memahami pengenalan pendidikan seks sejak dini untuk membantu anak terhindar dari tindakan kekerasan seksual. Terjadinya kekerasan seksual pada banyak dilatarbelakangi oleh minimnya pengetahuan anak tentang perlakuan orang dewasa dengan menyentuh tubuh anak. Anak belum paham tentang bagian tubuhnya yang boleh dan tidak boleh disentuh oleh orang lain. Maka untuk mengatasi hal tersebut pendidikan seks sejak dini pada tema Sendiri dan sub tema Tubuhku sangat penting diberikan pada anak. Hasil penelitian menunjukkan bahwa program pendidikan seks efektif dapat meningkatkan kemampuan proteksi diri dari eksploitasi pada anak usia dini. Program dapat diterapkan dan menjadi bagian dari sekolah. (Akbar \& Mudzdaliffah, 2012, p. 5).

Pemilihan media pembelajaran juga menjadi salah satu faktor yang menentukan suatu proses pembelajaran menjadi efektif. Media pembelajaran tidak hanya berfungsi sebagai alat peraga semata, lebih dari itu media merupakan sarana penyampaian informasi atau pesan pembelajaran yang ingin disampaikan guru kepada anak didik. Melalui media, pembelajaran akan lebih terarah, memudahkan anak didik untuk mengetahui dan memahami materi pembelajaran, dan yang paling penting dengan adanya media pembelajaran menjadi lebih menarik dan tidak monoton (Fadlillah, 2016). Pemanfaatan media gambar akan membuat siswa sangat antusias memperhatikan materi yang disampaikan sehingga suasana kelas menjadi menarik dan tidak monoton, serta menjadikan siswa belajar dengan santai, tidak tegang dan menyenangkan (Kamsiyatun, 2016, p. 101)

Media gambar tubuh yang digunakan di TK Muslimat NU VI Pademawu Pamekasan sebagai alat peraga dalam pengenalan pendidikan seks pada anak adalah termasuk jenis media visual. Media visual yang mengutamakan penglihatan langsung dipandang sangat cocok untuk digunakan dalam pembelajaran anak usia dini karena dengan apa yang dilihat anak akan lebih mudah mengetahui dan memahami materi pembelajaran. Maka pemilihan media pembelajaran juga harus disesuaikan dengan materi pembelajaran yang akan disampaikan. Seorang guru harus bisa menentukan pemilihan media secara tepat mulai dari media audio, visual, audio visual, lingungan, ataupun media permainan (Fadlillah, 2016).

Konsep pembelajaran di PAUD hendaknya dilakukan dengan cara yang mudah, menarik, menyenangkan, dan bersifat bermain sehingga merangsang anak untuk berpartisipasi 
aktif dan mampu menstimulasi semua aspek perkembangan anak. Salah satu manfaat media pembelajaran yang patut dijadikan pertimbangan oleh seorang guru adalah bahwa media tersebut dapat membangkitkan keinginan dan minat baru. Media dapat membangkitkan motivasi dan merangsang siswa untuk belajar (Fadlillah, 2016). Hasil penelitian menunjukkan bahwa penggunaan media gambar meningkatkan pemahaman anak karena dengan media tersebut anak lebih tertarik dan lebih berpartisipasi aktif serta meningkatkan kemampuan belajar membaca pada anak (Supriyanti, 2016, p. 829).

Selain penggunaan media yang menarik, pemilihan metode pembelajaran juga harus tepat sesuai dengan kemampuan dan karakteristik peserta didik. Metode pembelajaran dapat diartikan sebagai suatu cara yang sistematis untuk melakukan aktivitas atau kegiatan pembelajaran yang bertujuan untuk mempermudah dalam mencapai tujuan pembelajaran yang diinginkan, sehingga materi yang disampaikan kepada peserta didik mudah dipahami dan dimengerti dengan baik, serta dapat diimplementasikan dalam kehidupan sehari-hari (Fadlillah, 2016). Metode pembelajaran di PAUD meliputi metode bermain, metode bercerita, metode tanya jawab, metode bernyanyi, metode bercakap-cakap, metode karya wisata, metode demontrasi, metode sosiodrama, dan metode eksperimen.

Salah satu metode pembelajaran untuk mengenalkan pendidikan seks di TK Muslimat NU VI Pademawu Pamekasan adalah metode bernyanyi yang disertai gerakan. Metode bernyanyi dilakukan secara bersama-sama antara guru dan murid. Metode bernyanyi merupakan salah satu metode pembelajaran anak usia dini yang berisi syai-syair lagu yang disesuaikan dengan materi yang akan diajarkan. Terkadang dalam menggunakan metode bernyanyi disertai dengan tepuk tangan dan menari (Fadlillah, 2016). Adapaun lirik lagu dalam mengenalkan pendidikan seks pada anak melalui metode bernyanyi di TK Muslimat NU VI Pademawu Pamekasan berisi tentang pesan-pesan atau informasi tentang bagian-bagian tubuh anak yang boleh dan tidak boleh disentuh orang lain.

Tidak kalah pentingnya juga dalam upaya mengenalkan pendidikan seks pada anak adalah sikap para pendidik baik orang tua maupun guru yang berperan sebagai orang yang menyampaikan informasi pendidikan baik di rumah maupun di sekolah, terlebih jika menyangkut hal-hal yang bersifat sensitif seperti masalah seksualitas. Orang tua maupun guru harus betul-betul memahami tahapan usia dan karakteristik perkembangan anak. Beberapa hal yang harus diperhatikan oleh orang tua maupun guru ketika berbicara seks atau menyampaikan materi pendidikan seks pada anak yaitu 1) meluangkan waktu untuk berdialog atau berdiskusi tentang seks pada anak dengan bahasa yang mudah dipahami oleh anak 2) bersikap terbuka, informative, yakin atau tidak ragu-ragu 3) penyampaian materi harus disesuaikan dengan usia anak 4) gunakan media yang konkret seperti gambar, boneka, dan binatang untuk memudahkan anak menyerap informasi 5) membekali diri dengan wawasan yang cukup untuk menjawab pertanyaan anak 6) menjawab pertanyaan dengan jujur dan tutur kata yang baik atau bahasa yang sopan 7) dalam memberika seks pada anak sebaiknya anak mengenali bagian tubuh dirinya sendiri dan jangan mengeksplor bagian tubuh orang lain 8) mendiskusikan kepada ahli atau psikolog jika mengalami hambatan yang tidak bisa diatasi sendiri 9) meyakinkan diri bahwa pendidikan seks pada anak adalah penting dan bermanfaat (Ratnasari \& Alias, 2016, p. 58). Justicia mengungkapan bahwa Orang tua maupun guru juga bisa menggunakan istilah PANTS (celana dalam) untuk menjelaskan pendidikan seks pada anak sebagaimana dikutip oleh Azzahra (2020) yaitu:

1) Private are private (pribadi adalah pribadi). Setiap apapun yang ditutupi oleh pakaian dalam tidak boleh ada yang melihat atau menyentuhnya

2) Always remember your body belongs to you (selalu ingat tubuhmu hanya milikmu). Anak harus tahu bahwa tubuh mereka adalah milik mereka dan orang lain tidak memiliki hak untuk melakukan sesuatu terhadap tubuh mereka

3) No, means no (tidak berarti tidak). Anak memiliki hak untuk tidak memperbolehkan siapapun menyentuh alat vitalnya

4) Talk about secret that upset you (tanyakan rahasia yang membuat anak gelisah). Mebantu anak merasa percaya diri ketika berbicaraa hal rahasia yang membuat anak merasa 
khawatir atau takut, misalnya dengan meyakinkan pada anak bahwa anak akan selalu dilindungi

5) Speak up, someone can help (bicaralah, seseorang akan membantu). Jika anak merasa sedih, cemas, khawatir, dan takut, berikan pengertian bahwa mereka dapat menceritakan rahasianya kepada orang tua atau guru yang mereka percaya dapat melindungi atau membantunya.

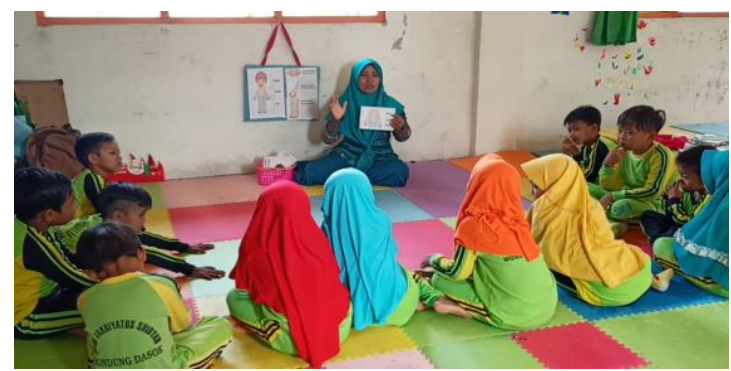

Gambar 4. Mengenalkan anggota tubuh dan fungsinya di dalam kelas

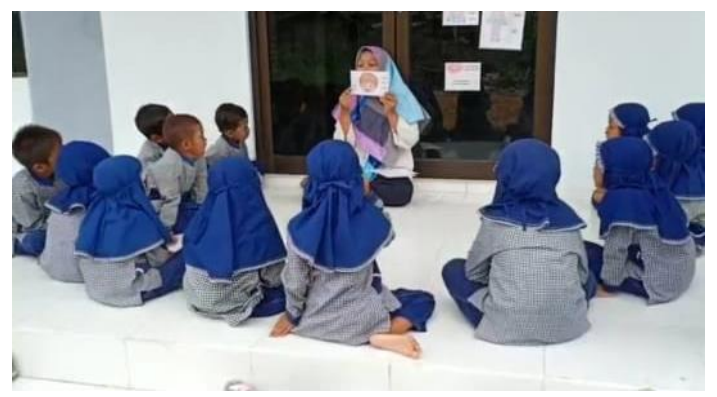

Gambar 5. Mengenalkan anggota tubuh dan fungsinya di dalam kelas

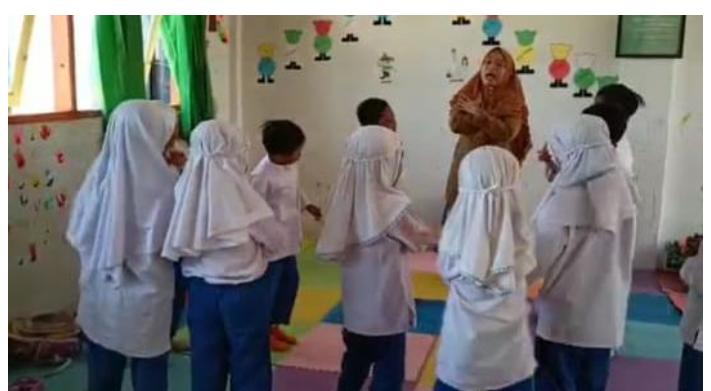

Gambar 6. Menyanyikan lagu sentuhan boleh dan sentuhan tidak boleh

\section{Simpulan dan Saran}

Dari hasil penelitian dapat disimpulkan bahwa mengenalkan pendidikan seks pada anak di TK Muslimat NU VI Pademawu Pamekasan dilaksanakan melalui pengenalan pendidikan kesehatan dan keselamatan diri yang mengacu pada tema Diri Sendiri dan subtema Tubuhku dalam kurikulum 13 PAUD dengan menggunakan media gambar dan metode bernyanyi. Agar pembelajaran tidak monoton dan anak tidak merasa bosan sebaiknya guru menambah referensi lagu-lagu baru dan media yang lebih variatif.

\section{Daftar Rujukan}

Akbar, Z., \& Mudzdaliffah, F. (2012). Program Pendidikan Seks Untuk Meningkatkan Proteksi Diri dari Eksploitasi Seksual Pada Anak Usia Dini. 25(16), 1-5.

Anggraini, T., Riswandi, \& Sofia, A. (2017). Pendidikan Seksual Anak Usia Dini: Aku dan Diriku. Jurnal Pendidikan Anak, 3(2), 1-14. 
Azzahra, Q. M. (2020). Pendidikan Seksual Bagi Anak Usia Dini: "my bodies belong to me." Jurnal Pendidikan: Early Childhood, 4(1), 77-86.

Chomaria, N. (2012). Pendidikan Seks Untuk Anak Dari Balita Hingga Dewasa. Solo: Aqwam Jembatan Ilmu.

Dewi, N. L. K. M., Putra, S., \& Suniasih, N. W. (2017). Pengaruh Penerapan Metode Bernyanyi Terhadap Kecerdasan verbal Linguistik Pada Anak Kelompok B1 TK Khumara Bhuana Peguyangan Denpasar Utara. E-Journal PAUD Universitas Pendidikan Ganesha, 5(2), 137-146.

Fadlillah, M. (2016). Desain Pembelajaran PAUD Tinjauan Teoritik \& Praktik. Jogjakarta: Ar Ruzz Media.

Fajrin, L. P., Junanto, S., \& Kurniasari, D. (2020). Implementasi Pendidikan Seks Pada Anak Usia Dini. PAUD Lectura: Jurnal Pendidikan Anak Usia Dini, 3(2), 78-87.

Haryono, S. E., Anggraini, H., Muntomimah, S., \& Wahyudi, D. (2018). Implementasi Pendidikan Sex Pada Anak Usia Dini Di Sekolah. Jurnal Akses Pengabdian Indonesia, 3(1), 24-34.

Hurlock, E. B. (1991). Psikologi Perkembangan Suatu Pendekatan Sepanjang Rentang Kehidupan. Jakarta: Erlangga.

Idayanti, T., Vidya, H., \& Mutikasari, S. (2017). Pengaruh Pendidikan Kesehatan dengan Penerapan Metode Bernyanyi Terhadap Kemampuan Mencuci Tangan Pada Siswa Kelas A1 Di RA Muslimat Darul Faizin I Desa Catak Gayam Mojowarno-Jombang. Jurnal Nurse and Health, 6(2), 44-54. https://doi.org/10.5281/zenodo.1464323

Jannah, S. H. (2021, January 12). Wawancara 3.

Jatmikowati, T. E., Angin, R., \& Ernawati. (2015). Model dan Materi Pendidikan Seks Anak Usia Dini Perspektif Gender Untuk Menghindarkan Sexual Abuse. Cakrawala Pendidikan, (3), 434-448.

Juhariyah. (2021, January 12). Wawancara 2.

Kamsiyatun. (2016). Pemanfaatan Media Gambar Untuk Meningkatkan Hasil Belajar Matematika Siswa Kelas IA SDN Sidomekar 08 Kecamatan Semboro Kabupaten Jember Thun Pelajaran 2014/2015. Pancaran, 5(2), 91-102.

Khotimah, S. H., Sunaryati, T., \& Suhartini, S. (2021). Penerapan Media Gambar Sebagai Upaya dalam Peningkatan Konsentrasi Belajar Anak Usia Dini. Jurnal Obsesi: Jurnal Pendidikan Anak Usia Dini, 5(1), 676-685. https://doi.org/10.31004/obsesi.v5i1.683

Lestari, A. A. \& Erik. (2017). Penggunaan Metode Bernyanyi Terhadap Peningkatan Kosakata Bahasa Inggris. Jurnal Pelita PAUD, 2(1), 1-13.

Mansur. (2014). Pendidikan Anak Usia Dini Dalam Islam. Yogyakarta: Pustaka Pelajar.

Mukti, A. (2016). Pendidikan Seks Untuk Anak Usia dini Perspektif Islam. Jurnal Harkat: Media Komunikkasi Gender, 12(2), 89-98.

Ratnasari, R. F., \& Alias, M. (2016). Pentingnya Pendidikan Seks Untuk Anak Usia DIni. Jurnal Tarbawi Khatulistiwa, 2(2), 55-59.

Solihin. (2015). Pendidikan Seks Untuk Anak Usia Dini. Jurnal Pendidikan Sekolah Dasar JPSD, 1(2), 56-74.

Suprapto, R., Hayati, M., Nubaity, S., Anggraeni, F., Haritsatama, S., Sadida, T. Q., ... Pratama, F. A. (2020). Pembiasaan Cuci Tangan yang Baik dan Benar Pada Siswa Taman KanakKanak (TK) di Semarang. Jurnal Surya Masyarakat, 2(2), 139-145.

Supriyanti. (2016). Peningkatan Kemampuan Berbahasa Melalui Media Gambar Anak Kelompok B I Di TK TKK Tunas Kartini Moyudan Sleman Yogyakarta. Jurnal Pendidikan Anak, 5(2), 825-830.

Zahrotun Naimah. (2021, January 12). Wawnacara 1.

Zubaedah, S. (2016). Pendidikan Seks Pada Anak Usia Dini di TK Islam Kota Yogyakarta. AlAthfal : Jurnal Pendidikan Anak, 2(2), 55-68. 